ISSN 1392-3196 / e-ISSN 2335-8947

Zemdirbyste-Agriculture, vol. 107, No. 1 (2020), p. 71-78

DOI 10.13080/z-a.2020.107.010

\title{
Nuclear DNA content and phenotypic traits of the Prunus rootstocks from Poland's gene resources
}

\author{
Małgorzata PODWYSZYŃSKA, Mirosław SITAREK, \\ Agnieszka MARASEK-CIOŁAKOWSKA, Urszula KOWALSKA
}

\author{
Research Institute of Horticulture \\ Konstytucji 3 Maja 1/3, 96-100 Skierniewice, Poland \\ E-mail: malgorzata.podwyszynska@inhort.pl
}

\begin{abstract}
The ploidy level can be useful in evaluating reproductive and somatic compatibility, an important parameter in scion and rootstock breeding programs. Evaluation of nuclear DNA content was performed in order to determine ploidy level of 31 rootstocks of genus Prunus for plum, sour cherry and sweet cherry. In the first stage of the research, the conditions of flow cytometry analysis with application of propidium iodide for DNA staining were optimized. Repeatable results and relatively good-quality histograms were obtained using Partec extraction buffer with 1\% PVP (polyvinylpyrrolidone) addition, with incubation time from 50 to $90 \mathrm{~min}$. The best internal standard for flow cytometry analysis proved to be tomato (Solanum lycopersicum L.) $2 \mathrm{C}=1.96 \mathrm{pg}$ for rootstocks with a nuclear DNA content from 0.55 to $1.64 \mathrm{pg}$, and soybean (Glycine $\max (\mathrm{L}$.) Merr.) $2.50 \mathrm{pg}$ for rootstocks with a larger nuclear DNA contents from 1.8 to $2.3 \mathrm{pg}$. In five plum rootstocks, $2 \mathrm{C}$ values ranged from 0.61 to $0.67 \mathrm{pg}$ indicating their diploid chromosome number. One rootstock was identified as tetraploid $(2 \mathrm{C}=1.34 \mathrm{pg})$, and four rootstocks as hexaploids owing to their DNA contents from 2.07 to $2.23 \mathrm{pg}$. One rootstock was considered a pentaploid due to its $2 \mathrm{C}$ value of $1.64 \mathrm{pg}$ which was approximately two and a half times more than in diploid Prunus sp. In nine cherry rootstocks, 2C DNA values ranged from 0.74 to $0.86 \mathrm{pg}$ indicating their diploid chromosome number. Nine cherry rootstocks were identified as triploids with their 2C DNA contents from 1.03 to $1.24 \mathrm{pg}$. Two cherry rootstocks were considered as tetraploids having $2 \mathrm{C}$ DNA of $1.39 \mathrm{pg}$. The ploidy level of cherry and plum rootstocks was evaluated in relation to morphological and agronomic traits. The tendency to increase the size of stomata and leaves along with an increase in the ploidy level was observed within Prunus rootstock genotypes; however, the correlations between these traits were not so evident. Therefore, stomata and leaf size cannot be considered as a morphological marker indicating ploidy level. The evaluated nuclear DNA contents / ploidy levels as well as stomata and leaf size are the additional descriptors of Prunus rootstocks that can be useful for identifying genotypes.
\end{abstract}

Key words: flow cytometry, hexaploids, pentaploids, ploidy level, plum, cherry rootstocks, tetraploids, triploids.

\section{Introduction}

It is well known that within one genus, the species and even cultivars of the same species differ in the content of nuclear DNA which translates into a ploidy level. It is believed that nuclear DNA content is a specific feature and its assessment by flow cytometry can be helpful in differentiating taxa. For many Prunus genotypes used as rootstocks for plum and cherry trees collected in gene resources of the Research Institute of Horticulture in Skierniewice, Poland, the nuclear DNA content is unknown. There are over 400 to 430 Prunus species, of which approximately one hundred is important for horticulture and breeding (Das et al., 2011). The species are grouped into four subgenera: Prunus, Cerasus, Amygdalus and Emplectocladus (Angiosperm Phylogeny Group, 2009). The main Prunus crops are peach, plum, apricot, cherry, almond and their various hybrids, e.g., plumcot. The Prunus taxa are mainly cultivated as fruit crops and several species are grown as ornamental plants.
Prunus crops like many other fruit crops are propagated by grafting and grown on rootstocks. Grafting onto rootstocks enables the grower to determine the tree's eventual size and improve environmental adaptability, such as tolerance to wet / dry soil conditions, acidity / alkalinity of soil or even hot/cold air temperature and resistance to various pests and diseases (Das et al., 2011). The basic chromosome number in Prunus is $\mathrm{x}$ $=8$ (Das et al., 2011). Somatic chromosome number of various Prunus species varies from diploid to hexaploid (Table 1). Most of the species are diploid $(2 \mathrm{n}=2 \mathrm{x}=16)$, e.g., $P$. dulcis, $P$. armeniaca, $P$. avium, $P$. canescens, P. cerasifera, $P$. lannesiana, $P$. mahaleb, $P$. munsoniana, $P$. persica, $P$. pumila and $P$. tomentosa. Some of these species ( $P$. avium, $P$. cerasifera and $P$. spinosa) occur in different polyploid forms. There are also several tetraploids $(2 \mathrm{n}=4 \mathrm{x}=32)$ such as $P$. cerasus, $P$. fruticosa and $P$. maackii, and hexaploids $(2 \mathrm{n}=6 \mathrm{x}=48)$ such as

Please use the following format when citing the article:

Podwyszyńska M., Sitarek M., Marasek-Ciołakowska A., Kowalska U. 2020. Nuclear DNA content and phenotypic traits of the Prunus rootstocks from Poland's gene resources. Zemdirbyste-Agriculture, 107 (1): 71-78. DOI 10.13080/z-a.2020.107.0010 
P. domestica and $P$. domestica var. insititia. Some of these Prunus species have been used for selecting improved rootstock genotypes or served as parental genotypes for creation of hybrid rootstock cultivars combining desired traits (Das et al., 2011).

At present, many rootstocks with different vigour and behaviour are available for plum, sour cherry and sweet cherry trees. The wide genetic diversity and adaptability of rootstocks allow different vegetativeproductive behaviours in an orchard. Effects of rootstock on the tree growth, tree productivity and fruit quality of different stone fruit crops was reported in numerous publications (Murri et al., 2013; Sitarek, 2017; Usenik et al., 2017).

The natural polyploid formation within the genus Prunus results from both somatic chromosome doubling and union of unreduced gametes with the latter considered most important polyploidisation mechanism (Ramsey, Schemske, 1998; Wang et al., 2018).

Since the nuclear DNA content and ploidy level of many Prunus rootstocks are unknown, the evaluation of these traits was performed in order to provide information for germplasm conservation and breeding. In this study, 2C DNA value (somatic nuclear DNA content) / ploidy level of Prunus rootstocks was evaluated in relation to stomata and leaf size as well as agronomic trait such as growth vigour. If the size of stomata and leaves and vigour were positively correlated with the level of ploidy, these features could be used as easy-to-use ploidy markers. Such knowledge would also be helpful in selecting parents for crosses in order to obtain hybrids with specific traits, e.g., dwarfing or semi dwarfing effect on tree vigour.

\section{Materials and methods}

Plant material. Studies were carried out in 2017-2018 in the Research Institute of Horticulture, Skierniewice, Poland. Thirty one Prunus genotypes, 11 rootstocks for plum trees and 20 rootstocks for cherry and sweet cherry, gathered in genetic resources of the Research Institute of Horticulture were used for the research.

Evaluation of nuclear DNA content. In the first stage of the research, the conditions of flow cytometry (FCM) analysis with application of propidium iodide (PI) for DNA staining FCM were optimized: type of buffer for nuclei extraction and incubation time (from 15 to $120 \mathrm{~min}$ ) as well as selection of internal standards (plant genotypes with known nuclear DNA content). Analysis of genome size was done using FCM. Samples were taken in mid-July from six leaves collected randomly from one plant of each genotype. Leaf tissue $\left(0.5-1 \mathrm{~cm}^{2}\right)$ was chopped together with a piece $\left(0.5-1 \mathrm{~cm}^{2}\right)$ of plant internal standard in a Petri dish in $1.5 \mathrm{~mL}$ nuclei isolation Galbraith's buffer (Galbraith et al., 1983) or Partec buffer (Sysmex Partec GmbH, Germany) with slight modification according to Śliwińska (2008) to which propidium iodide $\left(50 \mu \mathrm{g} \mathrm{mL} \mathrm{m}^{-1}\right)$, RNase $(50 \mu \mathrm{g} \mathrm{mL}-1)$ and 1\% PVP (polyvinylpyrrolidone) were added. As the internal standards, the young leaves of tomato (Solanum lycopersicum L.) 'Stupicke' were used (2C DNA = 1.96 pg (Doležel et al., 1992), soybean (Glycine max L. Merr.) 'Polanka' 2C DNA $=2.50$ pg (Doležel et al., 1994) or maize (Zea mays L.) CE-777 2C DNA $=5.43$ pg (Lysak, Doležel, 1998) were used. The seeds of reference plants were kindly provided by Institute of Experimental Botany, Czech Republic. Optimization of FCM analysis was performed with reference plants of Prunus genotypes (external standards) with the known chromosome numbers: diploid $P$. cerasifera var. divaricata Led. 'Anna' (myrobalan) $(2 \mathrm{n}=2 \mathrm{x}=16)$, triploid sweet cherry rootstock GiSelA 3 (P. cerasus 'Schattenmorelle' $x$ $P$. canescens $)(2 \mathrm{n}=3 \mathrm{x}=24)$ and haxaploid $P$. domestica 'Eruni' $(2 \mathrm{n}=6 \mathrm{x}=48)$.

After adding $1.5 \mathrm{~mL}$ of the isolation buffer, the samples were filtered through a $30 \mu \mathrm{m}$ filter and incubated for 50-60 $\mathrm{min}$ in room temperature. The fluorescence of the nuclei was measured using analyser CyFlow Ploidy (Sysmex Partec) with an Nd-YAG green laser at $532 \mathrm{~nm}$. Data were analysed by means of software CyView (Sysmex Partec). The 2C DNA content of a sample was calculated as the sample peak mean divided by the mean of the standard plant peak and multiplied by the amount of DNA of the standard plant. Samples with at least 5000 nuclei were measured for six leaves of each plant with two runs from each nuclei isolation extract. The ploidy level of rootstocks was evaluated in relation to stomata and leaf size and vigour. The latter feature was classified as weak, intermediate vigour, vigorous or very vigorous, depending on the impact of the rootstock on the tree growth in the orchard, described according to the literature (Murri et al., 2013; Sitarek, 2017; Usenik et al., 2017).

In Table 1, the nuclear 2C DNA contents and/or ploidy levels according to different authors are presented for the Prunus species which are present in pedigree of the rootstocks for plums and cherries evaluated in our study. This information was helpful in indicating ploidy levels of Prunus genotypes based on FCM analysis and was also used in discussion.

Phenotype evaluation. Leaves were collected in late May and June. Leaf area was measured for randomly collected 30 leaves, with an optical planimeter Area Meter AM 350 (ADC Bioscientific, UK). The leaves for measurement of stomata length were collected in mid-June. The abaxial epidermis was isolated from the middle part of the leaves with a transparent adhesive tape and stained with toluidine blue and mounted on slides for microscopic observations according to the procedure of Dyki and Habdas (1996). The stomata measurements were determined for five leaves $(\times 20$ stomata $)$ of each genotype using a Nikon Eclipse $80 \mathrm{i}$ microscope with the program NIS-Elements BR 2.30 (Nikon Instruments Europe BV, The Netherlands) at 400× magnification.

Statistical analysis. Data of all parameters were analysed with analysis of variance (ANOVA)-nested design. All calculations were done with the package Statistica, version 10 (StatSoft Inc., USA). The means were compared by Tukey's test at $p=0.05$.

\section{Results}

Repeatable results and relatively good-quality histograms were obtained using Partec extraction buffer with 1\% PVP addition, with incubation time from 50 to $130 \mathrm{~min}$. The best internal standard for FCM analysis of the rootstocks for plums and cherries with a nuclear DNA content from about 0.7 to $1.4 \mathrm{pg}$ proved to be Solanum lycopersicum $(2 \mathrm{C}=1.96 \mathrm{pg})$, of which peaks $2 \mathrm{C}$ and $4 \mathrm{C}$ did not coincide with the peaks of the genotypes tested (Fig. 1). However, peaks of S. lycopersicum overlapped partially with the peaks of Prunus genotypes with larger genomes tested. For rootstock genotypes with a nuclear DNA contents from 1.8 to $2.3 \mathrm{pg}$, Glycine $\max (2.50 \mathrm{pg})$ was selected as the internal standard. In the second stage, the optimized method and well-chosen internal standards allowed to assess with high precision the nuclear DNA content / ploidy level of 31 Prunus genotypes of the rootstocks for plums and cherries. 
Table 1. Ploidy levels and nuclear DNA contents of reference Prunus genotypes, which are the parental genotypes for rootstock for plum, cherry and sweet cherry trees

\begin{tabular}{|c|c|c|c|c|}
\hline Genotype & $\begin{array}{c}\text { Ploidy } \\
\text { level }\end{array}$ & $\begin{array}{l}\text { References for } \\
\text { ploidy level }\end{array}$ & $\begin{array}{l}\text { Nuclear 2C DNA } \\
\text { content (pg), } \\
\text { references }\end{array}$ & $\begin{array}{c}\text { References for } \\
\text { nuclear DNA } \\
\text { content* }\end{array}$ \\
\hline $\begin{array}{l}\text { P. amygdalus Batsch, syn. Prunus dulcis, } \\
\text { almond }\end{array}$ & $2 \times$ & $\mathrm{B}, \mathrm{D}, \operatorname{Pr}$ & 0.66 & $\mathrm{~B}$ \\
\hline P. armeniaca L., apricot & $2 \times$ & Dic, D, Pr & $0.61,0.60$ & Ar, Dic, Di \\
\hline P. avium (L.) L., sweet cherry & $2 \times, 3 \times, 4 \times$ & Dic, D, Pr, W & $0.70,0.67$ & Ar, Dic, Di \\
\hline P. canescens Bois, hoary cherry & $2 \times$ & $\mathrm{D}, \mathrm{Pr}$ & & \\
\hline P. cerasifera, cherry plum & $2 \times, 2 \times+1,3 \times, 4 \times, 6 \times$ & $\mathrm{D}$ & & \\
\hline P. cerasus L., sour cherry & $4 \times$ & Dic, $D, \operatorname{Pr}$ & $1.24,1.36-1.42$ & Ar, Dic, Di \\
\hline P. domestica L., plum & $6 \times$ & Dic, $\mathrm{D}, \mathrm{Z}$ & $1.83,1.83,1.86,2.10$ & Ar, Dic, Di, Z \\
\hline P. domestica ssp. insititia L., damson & $3 \times, 6 \times$ & D, BT, Pr, Z & $2.14,1.99-2.13$ & $\mathrm{Z}, \mathrm{BT}$ \\
\hline P. fruticosa Pall., European dwarf cherry & $4 \times$ & $\mathrm{D}, \operatorname{Pr}$ & & \\
\hline P. incisa Thunb., Fuji cherry & $2 \times$ & $\operatorname{Pr}$ & & \\
\hline P. maackii, manchurian cherry & $4 \times$ & $\mathrm{P}, \mathrm{Pr}$ & $0.96-0.97$ & $\mathrm{P}$ \\
\hline $\begin{array}{l}\text { P. lannesiana (Carriere) E.H. Wilson, } \\
\text { syn. P. serrulata var. lannesiana, } \\
\text { Japanese cherry }\end{array}$ & $2 \times, 3 \times$ & Pr, W & & \\
\hline P. mahaleb L., mahaleb cherry & $2 \times$ & $\mathrm{D}, \mathrm{Pr}$ & & \\
\hline $\begin{array}{l}\text { P. munsoniana, W.Wight \& Hedrick, } \\
\text { wild-goose plum }\end{array}$ & $2 \times$ & E, $\operatorname{Pr}$ & & \\
\hline \multirow{4}{*}{$\begin{array}{l}\text { P. persica }(\mathrm{L} .) \text { Batsch, } \\
\text { peach }\end{array}$} & $2 \times$ & \multirow{4}{*}{ Dic, D, Pr } & $0.54-0.55$ & Ar, Dic, Di \\
\hline & $2 \times$ & & $0.58-0.64$ & $\mathrm{~B}$ \\
\hline & $3 \times($ polyploidistion $)$ & & 0.98 & $\mathrm{~B}$ \\
\hline & $4 \times($ polyploidisation $)$ & & 1.23 & $\mathrm{~B}$ \\
\hline P. psudocerasus Lindl., Cambridge cherry & $4 \times, 5 \times, 6 \times$ & $\mathrm{G}, \mathrm{W}$ & & \\
\hline P. pumila L., sand cherry & $2 \times$ & $\operatorname{Pr}$ & & \\
\hline P. salicina Lindl., Japanese plum & $2 \times, 4 \times$ & $\mathrm{D}, \mathrm{BT}, \mathrm{Pr}, \mathrm{W}$ & $0.44-0.97$ & BT \\
\hline P. spinosa L., blackthorn & $2 \times, 3 \times, 4 \times, 5 \times, 6 \times$ & $\mathrm{D}, \mathrm{O}, \mathrm{Pr}, \mathrm{Z}$ & 1.40 & $\mathrm{Z}$ \\
\hline P. tomentosa Thunb., nanking cherry & $2 \times$ & $\mathrm{D}, \mathrm{W}$ & 0.57 & $\mathrm{~B}$ \\
\hline GiSelA & $3 \times$ & $\mathrm{V}$ & & \\
\hline
\end{tabular}

* - the letters in columns indicate references for ploidy levels or nuclear DNA contents: Ar - Arumuganathan, Earle (1991), B Baird et al. (1994), BT - Ben Tamarzizt et al. (2015), D - Das et al. (2011), Dic - Dickson et al. (1992), Di - Dirlewanger et al. (2009), G - Gu et al. (2014), O - Okie, Weinberger (1996), P - Pooler et al. (2012), Pr - Prunus Vulnerability Statement (2017), V - Vujović et al. (2012), W - Wang et al. (2018), Z - Žabka et al. (2018).
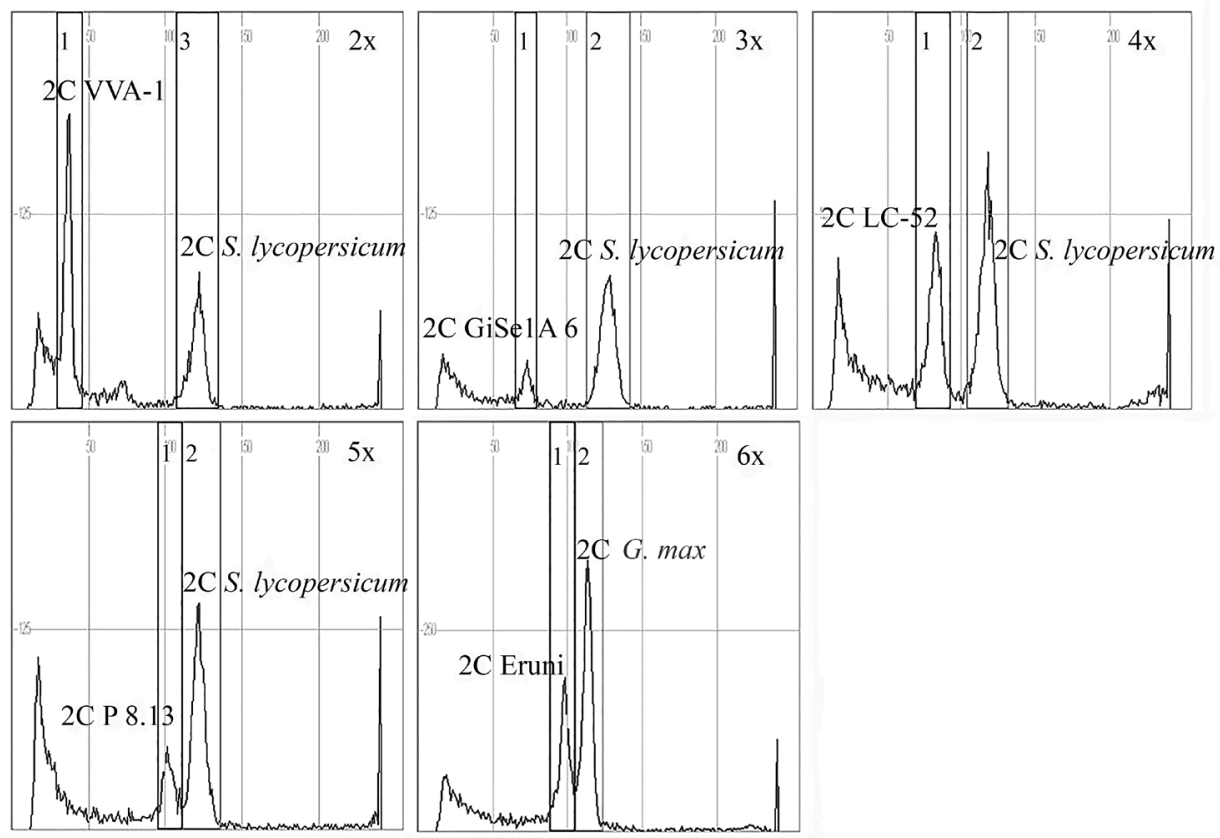

$2 \times$ - diploid plum rootstock VVA-1, 3× - triploid cherry rootstock GiSelA 6, 4× - tetraploid cherry rootstock LC-52, 5× - pentaploid plum rootstock 'Mariana P 8.13', 6× - hexaploid plum rootstock 'Eruni'

Figure 1. Histograms of nuclear DNA / ploidy level estimation using flow cytometry (FCM) with internal standards: Solanum lycopersicum $(2 \mathrm{C}$ DNA $=1.96 \mathrm{pg}$ ) for the taxa of nuclear DNA content below $1.70 \mathrm{pg}$ and Glycine max $(2 \mathrm{C} \mathrm{DNA}=2.50 \mathrm{pg})$ for hexaploid genomes $(2.07-2.24 \mathrm{pg})$ 
For the reference Prunus genotypes of the known chromosome number, 2C DNA values were $0.68 \mathrm{pg}$ for diploid $P$. cerasifera var. divaricata Led. 'Anna', 1.18 pg for triploid GiSelA 3 ( $P$. cerasus 'Schattenmorelle' $\times$ P. canescens) and $2.16 \mathrm{pg}$ for hexaploid $P$. domestica 'Eruni' (Table 2). In four plum rootstock genotypes ('Ferciana Ishtara', VVA-1, 'Druzba' and GF 667), $2 \mathrm{C}$ values ranged from 0.61 to $0.67 \mathrm{pg}$ indicating their diploid chromosome number. One rootstock 'Fereley Jaspi' was identified as tetraploid $(2 \mathrm{C}=1.34 \mathrm{pg})$ and three rootstocks as hexaploids ('St. Julien A', 'Pixy' and GF 655/2) owing to their DNA contents from 2.07 to $2.23 \mathrm{pg}$. The rootstock 'Mariana P 8.13' was considered pentaploid due to its $2 \mathrm{C}$ value of $1.64 \mathrm{pg}$, which was approximately two and a half times more than in diploid Prunus sp. (2C DNA $=0.66 \mathrm{pg})$.

In nine rootstocks for cherry trees: $F$ 12/1, PiKu 1, Piku 3, INRA SL 64, 'Maxma Delbard 14 Brokforest', 'Ferci SL 405', GM 79, LC-13 and L-2, 2C DNA values ranged from 0.55 to $0.86 \mathrm{pg}$ indicating their diploid chromosome number (Table 2). Nine rootstocks were identified as triploids: 'Colt', GiSelA 3, GiSelA 5, GiSelA 6, P-HL A, P-HL C, PiKu 4, VSL-1 and VSL-2, with their 2C DNA contents from 1.03 to $1.24 \mathrm{pg}$. Two rootstocks were considered tetraploid: WC-13 and LC52 , having 2C DNA of $1.39 \mathrm{pg}$.

Genotypes differ significantly in the leaf size and stomata length (Tables $2-3$, Figs 2-3). Within rootstocks

Table 2. Nuclear DNA contents and ploidy levels of Prunus genotype rootstocks for plum, sour cherry and sweet cherry trees in relation to the leaf area, stomata length and vigour level

\begin{tabular}{|c|c|c|c|c|c|c|}
\hline Genotype & Parentage & $\begin{array}{c}\text { Nuclear } \\
\text { 2C DNA } \\
\text { content pg } \\
\end{array}$ & $\begin{array}{l}\text { Ploidy } \\
\text { level }\end{array}$ & $\underset{\mathrm{cm}^{2}}{\text { Leaf area }}$ & $\begin{array}{l}\text { Stomata length } \\
\mu \mathrm{m}\end{array}$ & $\begin{array}{l}\text { Vigour } \\
\text { level }\end{array}$ \\
\hline \multicolumn{7}{|c|}{ Rootstocks for plum trees } \\
\hline VVA-1 (Krymsk 1) & $\begin{array}{l}\text { P. tomentosa } \times \\
P . \text { cerasifera }\end{array}$ & $0.61 \pm 0.003$ & $2 \times$ & $16.3 \mathrm{~d}-\mathrm{c}$ & $24.1 \pm 2.38 \mathrm{~d}$ & intermediate vigour \\
\hline Druzba & P. pumila $\times$ P. armeniaca & $0.65 \pm 0.006$ & $2 \times$ & $15.2 \mathrm{~d}-\mathrm{g}$ & $22.1 \pm 2.39 \mathrm{e}$ & very vigorous \\
\hline Ferciana Ishtara & $\begin{array}{l}\text { P. salicina 'Belsiana' } \times \\
(P . \text { cerasifera } \times P \text {. persica })\end{array}$ & $0.67 \pm 0.013$ & $2 \times$ & $20.9 \mathrm{~cd}$ & $21.4 \pm 2.98 \mathrm{e}$ & vigorous \\
\hline GF 677 & (P. persica $\times$ P. amygdalus $)$ & $0.67 \pm 0.000$ & $2 \times$ & $26.3 \mathrm{ab}$ & $30.2 \pm 3.08 \mathrm{a}$ & vigorous \\
\hline Myrobalan & P. cerasifera var. divaricata & $0.68 \pm 0.005$ & $2 \times$ & $11.4 \mathrm{~g}$ & $15.9 \pm 3.32 \mathrm{~g}$ & very vigorous \\
\hline Fereley Jaspi & $\begin{array}{l}P \text {. salicina 'Methley' } \times \\
P \text {. spinosa }\end{array}$ & $1.34 \pm 0.017$ & $4 \times$ & $14.8 \mathrm{fg}$ & $21.3 \pm 2.43 \mathrm{e}$ & vigorous \\
\hline Mariana P 8.13 & P. cerasifera $\times$ P. munsoniana & $1.64 \pm 0.039$ & $5 \times$ & $20.1 \mathrm{~d}$ & $19.6 \pm 1.99 \mathrm{f}$ & very vigorous \\
\hline Pixy & P. insititia & $2.07 \pm 0.250$ & $6 \times$ & $22.4 \mathrm{bc}$ & $26.8 \pm 2.64 \mathrm{c}$ & weak \\
\hline Eruni & P. domestica & $2.16 \pm 0.057$ & $6 \times$ & $30.8 \mathrm{a}$ & $21.7 \pm 2.81 \mathrm{e}$ & intermediate vigour \\
\hline GF 655/2 & P. insititia & $2.21 \pm 0.029$ & $6 \times$ & $19.9 \mathrm{c}-\mathrm{e}$ & $28.3 \pm 2.54 \mathrm{~b}$ & intermediate vigour \\
\hline St. Julien A & P. insititia & $2.23 \pm 0.017$ & $6 \times$ & $19.3 \mathrm{c}-\mathrm{f}$ & $24.8 \pm 2.50 \mathrm{~d}$ & intermediate vigour \\
\hline \multicolumn{7}{|c|}{ Rootstocks for sour cherry and sweet cherry trees } \\
\hline LC-13 & $P$. avium $\times P$. cerasus & $0.55 \pm 0.008$ & $2 \times$ & $13.3 \mathrm{k}$ & $18.9 \pm 2.98 \mathrm{kl}$ & intermediate vigour \\
\hline Ferci SL 405 & P. mahaleb & $0.75 \pm 0.013$ & $2 \times$ & $18.9 \mathrm{~h}-\mathrm{k}$ & $25.7 \pm 3.36 \mathrm{c}-\mathrm{e}$ & vigorous \\
\hline INRA SL 64 & P. mahaleb & $0.75 \pm 0.006$ & $2 \times$ & $19.7 \mathrm{~h}-\mathrm{k}$ & $25.2 \pm 2.39 \mathrm{~d}-\mathrm{f}$ & vigorous \\
\hline L-2 (Krymsk 7) & P. lannesiana & $0.77 \pm 0.010$ & $2 \times$ & $15.9 \mathrm{jk}$ & $23.7 \pm 2.02 \mathrm{gh}$ & intermediate vigour \\
\hline $\mathrm{PiKu} 3$ (4.83) & $\begin{array}{l}\text { P. pseudocerasus } \times \\
(P . \text { canescens } \times P \text {. incisa })\end{array}$ & $0.77 \pm 0.010$ & $2 \times$ & $21.1 \mathrm{~h}-\mathrm{j}$ & $24.9 \pm 2.45 \mathrm{~d}-\mathrm{g}$ & vigorous \\
\hline $\begin{array}{l}\text { Maxma Delbard } 14 \\
\text { Brokforest }\end{array}$ & P. avium $\times$ P. mahaleb & $0.79 \pm 0.006$ & $2 \times$ & $32.2 \mathrm{~d}-\mathrm{f}$ & $24.1 \pm 2.59 \mathrm{f}-\mathrm{h}$ & vigorous \\
\hline GM 79 (Camil) & P. canescens & $0.80 \pm 0.021$ & $2 \times$ & $33.6 \mathrm{de}$ & $20.1 \pm 2.34 \mathrm{k}$ & intermediate vigour \\
\hline $\mathrm{PiKu} 1$ (4.20) & $\begin{array}{l}\text { P. avium } \times \\
(P \text {. canescens } \times P \text {. tomentosa })\end{array}$ & $0.81 \pm 0.008$ & $2 \times$ & $20.2 \mathrm{~h}-\mathrm{k}$ & $23.4 \pm 2.31 \mathrm{hi}$ & weak \\
\hline $\mathrm{F} 12 / 1$ & P. avium & $0.86 \pm 0.013$ & $2 \times$ & $45.3 \mathrm{~b}$ & $22.3 \pm 2.07 \mathrm{ij}$ & very vigorous \\
\hline Colt & $\begin{array}{l}\text { P. avium }(\mathrm{F} 299 / 2) \times \\
\text { P. pseudocerasus }\end{array}$ & $1.03 \pm 0.039$ & $3 \times$ & $57.8 \mathrm{a}$ & $24.5 \pm 2.88 \mathrm{e}-\mathrm{h}$ & very vigorous \\
\hline $\mathrm{PiKu} 4$ (4.22) & $\begin{array}{l}(P . \text { canescens } \times P . \text { tomentosa }) \\
\times P \text {. avium }\end{array}$ & $1.12 \pm 0.022$ & $3 \times$ & $31.6 \mathrm{~d}-\mathrm{f}$ & $22.2 \pm 2.39 \mathrm{ij}$ & intermediate vigour \\
\hline VSL-1 & P. fruticosa $\times$ P. lannesiana & $1.12 \pm 0.029$ & $3 \times$ & $22.3 \mathrm{~g}-\mathrm{i}$ & $25.0 \pm 2.79 \mathrm{~d}-\mathrm{f}$ & intermediate vigour \\
\hline VSL-2 (Krymsk 5) & P. fruticosa $\times$ P. lannesiana & $1.12 \pm 0.029$ & $3 \times$ & $15.1 \mathrm{jk}$ & $26.1 \pm 3.16 \mathrm{~cd}$ & vigorous \\
\hline GiSelA 5 (146/2) & $\begin{array}{l}\text { P. cerasus 'Schattenmorelle' } \\
\times \text { P. canescens }\end{array}$ & $1.13 \pm 0.017$ & $3 \times$ & $29.4 \mathrm{~d}-\mathrm{f}$ & $21.8 \pm 2.45 \mathrm{j}$ & intermediate vigour \\
\hline GiSelA $6(148 / 1)$ & $\begin{array}{l}\text { P. cerasus 'Schattenmorelle' } \\
\times \text { P. canescens }\end{array}$ & $1.14 \pm 0.005$ & $3 \times$ & $29.0 \mathrm{e}-\mathrm{g}$ & $27.0 \pm 3.58 \mathrm{bc}$ & intermediate vigour \\
\hline GiSelA $3(209 / 1)$ & $\begin{array}{l}\text { P. cerasus 'Schattenmorelle' } \\
\times \text { P. canescens }\end{array}$ & $1.18 \pm 0.005$ & $3 \times$ & $21.0 \mathrm{~h}-\mathrm{j}$ & $26.2 \pm 2.54 \mathrm{~cd}$ & weak \\
\hline P-HL A (84) & $P$. avium $\times P$. cerasus & $1.20 \pm 0.015$ & $3 \times$ & $41.9 \mathrm{bc}$ & $25.7 \pm 2.91 \mathrm{c}-\mathrm{e}$ & intermediate vigour \\
\hline P-HL C (6) & $(P$. avium $\times$ P. cerasus $)$ & $1.24 \pm 0.037$ & $3 \times$ & $48.3 \mathrm{~b}$ & $25.2 \pm 2.52 \mathrm{~d}-\mathrm{f}$ & weak \\
\hline LC-52 (Krymsk 6) & $\begin{array}{l}\text { P. cerasus 'Lyubskaya' } \times \\
\text { (P. cerasus 'Michurin' } \times \\
\text { P. maackii) }\end{array}$ & $1.39 \pm 0.010$ & $4 \times$ & $25.6 \mathrm{fg}$ & $30.8 \pm 3.02 b$ & intermediate vigour \\
\hline WC-13 & $\begin{array}{l}\text { P. cerasus 'Vladimirskaya' } \times \\
\text { (P. cerasus 'Michurin' } \times \\
\text { P. maackii) }\end{array}$ & $1.39 \pm 0.012$ & $4 \times$ & $36.7 \mathrm{~cd}$ & $27.8 \pm 3.02 \mathrm{~b}$ & intermediate vigour \\
\hline
\end{tabular}

Note. The mean separation within columns by Tukey's test at $p=0.05$; the means followed by the same letter do not differ at $p=0.05$. 

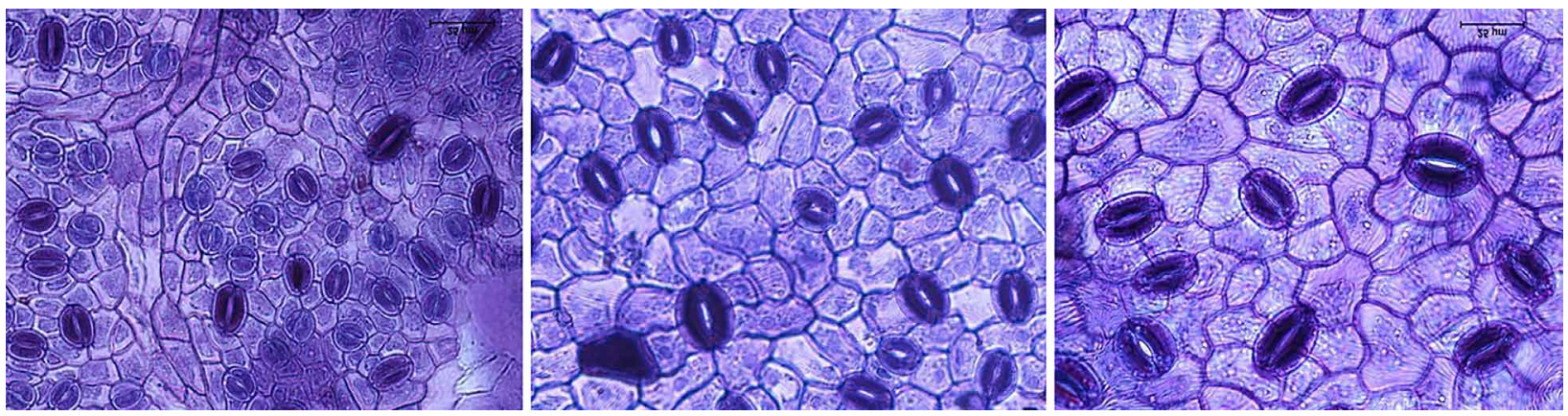

Figure 2. Stomata of plum rootstocks, from the left: diploid myrobalan (with very small and the incidental larger stomata), hexaploid 'Eruni' and hexaploid GF 655/2 with large stomata $(\mathrm{bar}=25 \mu \mathrm{m})$
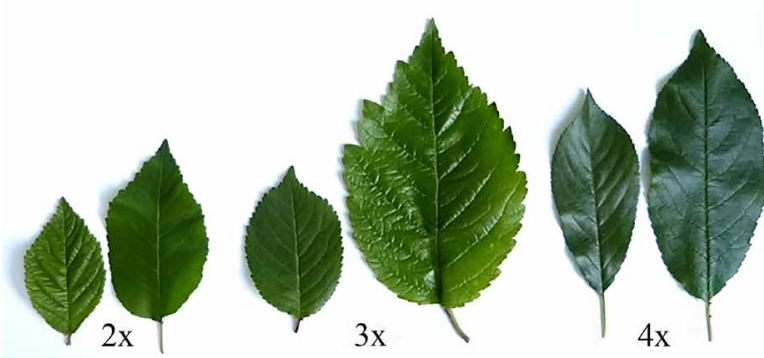

Figure 3. Leaves of cherry rootstocks: diploids LC-13 and 'Maxma Delbard' $(2 \times)$, triploids VSL-1 and 'Colt' $(3 \times)$ and tetraploids LC-53 and WC-13 (4×)

for plums, the smallest stomata with size of 15.9 and 19.6 $\mu \mathrm{m}$, were recorded for diploid myrobalan and pentaploid 'Mariana P 8.13' and the largest stomata, 28.3 and $30.2 \mu \mathrm{m}$, for hexaploid GF $655 / 2$ and diploid GF 677, respectively. The intermediate stomata lengths ranging from 21.3 to $24.1 \mu \mathrm{m}$ were observed for three diploid, one tetraploid and one hexaploid plum rootstocks. Within the plum rootstocks of the smallest leaves $\left(11.4-16.3 \mathrm{~cm}^{2}\right)$, there were three diploids, including myrobalan, and one tetraploid genotype. Among the plum rootstocks having intermediate and larger leaves $\left(19.3-30.8 \mathrm{~cm}^{2}\right)$, there were two diploids, one pentaploid and four hexaploids with the largest leaves recorded for hexaploid 'Eruni'.

Within cherry rootstocks, the correlation of stomata size and ploidy level was more evident (Tables $2-3)$. Among 10 genotypes of the smaller stomata (18.9$24.9 \mu \mathrm{m})$, there were eight diploids and two triploids while within cherry rootstocks of larger stomata (25.0 $30.8 \mu \mathrm{m})$, there were two diploids, six triploids and two tetraploids. However, the tendency in the increase of leaf size with the increase in the ploidy level was not so clear. The smallest leaves were observed for diploid LC$13\left(13.3 \mathrm{~cm}^{2}\right)$ and triploid VSL-2 $\left(15.1 \mathrm{~cm}^{2}\right)$ while the largest leaves 48.3 and $57.8 \mathrm{~cm}^{2}$ were found for triploids P-HL C and 'Colt', respectively. In turn, tetraploids WC13 and LC-52 had leaves of intermediate size.

Table 3. Effect of ploidy level on leaf area and stomata length of Prunus rootstocks

\begin{tabular}{ccc|ccc}
\hline \multicolumn{3}{c|}{ Rootstocks for plum trees } & \multicolumn{3}{c}{ Rootstocks for sour cherry and sweet cherry trees } \\
\hline \multirow{2}{*}{ ploidy level } & $\begin{array}{c}\text { leaf area } \\
\mathrm{cm}^{2}\end{array}$ & $\begin{array}{c}\text { stomata length } \\
\mu \mathrm{m}\end{array}$ & ploidy level & $\begin{array}{c}\text { leaf area } \\
\mathrm{cm}^{2}\end{array}$ & $\begin{array}{c}\text { stomata length } \\
\mu \mathrm{m}\end{array}$ \\
\hline $2 \times$ & $18.1 \mathrm{bc}$ & $22.5 \mathrm{~b}$ & $2 \times$ & $24.3 \mathrm{~b}$ & $23.6 \mathrm{c}$ \\
$4 \times$ & $14.8 \mathrm{c}$ & $21.3 \mathrm{~b}$ & $3 \times$ & $32.9 \mathrm{a}$ & $24.8 \mathrm{~b}$ \\
$5 \times$ & $20.1 \mathrm{ab}$ & $19.6 \mathrm{c}$ & $4 \times$ & $31.2 \mathrm{a}$ & $29.3 \mathrm{a}$ \\
$6 \times$ & $23.1 \mathrm{a}$ & $25.4 \mathrm{a}$ & & 0.00 & 0.00 \\
\hline$p$ & 0.00 & 0.00 & \multicolumn{4}{c}{} \\
\hline
\end{tabular}

Note. The mean separation within columns by Tukey's test at $p=0.05$; the means followed by the same letter do not differ at $p=0.05$.

In general, comparison of averages for individual ploidy levels showed a tendency to increase the size of stomata along with an increase in the level of ploidy (Table 3). Such tendency was observed in rootstocks for sweet and sour cherries. In plum rootstocks, only hexaploids had on average significantly larger stomata and leaves compared to other ploidy levels. In rootstocks for cherries, triploid and tetraploid levels had on average significantly larger stomata and leaves compared to diploid level. It should be noted that pentaploids and hexaploids were not detected among cherry rootstocks.

\section{Discussion}

The ploidy level as well as DNA content of Prunus sp. was first estimated using FCM analysis by Arumuganathan and Earle (1991). These authors assessed the nuclear DNA amount for six species of Prunus, reporting 2C DNA values $0.54-0.70 \mathrm{pg}$ for diploids, 1.24-1.42 pg for tetraploids and $1.83 \mathrm{pg}$ for hexaploids. Later, Dickson et al. (1992) evaluated 2C DNA of nine Prunus species and cultivars, and evaluations of these authors for particular ploidy levels were very similar. The authors mentioned above found that the genome size showed little variation within the diploid species of genus Prunus with the smallest value for $P$. persica and the largest for P. avium.

In our study, similar variation in 2C DNA values of diploid taxa especially within cherry rootstocks was observed. These values ranged from $0.55 \mathrm{pg}$ for LC-13 to $0.86 \mathrm{pg}$ for $\mathrm{F} 12 / 1$. Besides, the latter was selected from $P$. avium. And this species was reported to have larger genome compared to other diploid species (Arumuganathan, Earle, 1991; Dickson et al., 1992). Such differences in nuclear DNA contents between cultivars or species possessing the same chromosome number 
and belonging to the same genus are widely known in other genera, e.g., Lilium (Van Tuyl, Boon, 1997), Malus (Korban et al., 2009; Podwyszyńska et al., 2016); Tulipa (Zonneveld, 2009) and Narcissus (Zonneveld, 2010). The nuclear 2C DNA content is therefore considered as one of the taxa descriptors.

Our analysis showed that F $12 / 1$ selected from $P$. avium had 2C DNA of $0.86 \mathrm{pg}$ while the values reported by other authors (Arumuganathan, Earle, 1991; Dickson et al., 1992) were lower (0.70 pg). Such differences between $2 \mathrm{C}$ values obtained for the same species and reported by various authors resulted probably from various FCM methods, in which different buffers and incubation times as well as various DNA staining methods and internal standards were used. It was reported that in Prunus, nuclear DNA content evaluation was performed using the following internal standards: chicken erythrocytes of $2 \mathrm{C}=2.33 \mathrm{pg}$ (Arumuganathan, Earle, 1991; Dickson et al., 1992; Baird et al., 1994), Glycine $\max 2 \mathrm{C}=2.50 \mathrm{pg}$ (Pooler et al., 2012; Ben Tamarzizt et al. 2015; Žabka et al., 2018) and Zea mays with $2 \mathrm{C}=5.43$ pg (Jedrzejczyk, Sliwinska, 2010). In our study, Solanum lycopersicum of $2 \mathrm{C}=1.96 \mathrm{pg}$ was considered the most suitable internal standard for evaluation of ploidy levels from diploid to pentaploid levels of Prunus genotypes. Only hexaploid taxa required another internal standard plant, namely Glycine max. Thus the peaks for $2 \mathrm{C}$ Prunus hexaploids overlapped with S. lycopersicum 2C pick, both having similar nuclear DNA contents.

In our study, five rootstocks for plum and nine rootstocks for cherries were identified as diploids, which correspond to their origin from diploid parents. Among diploid rootstocks, myrobalan was selected from diploid $P$. cerasifera var. divaricata and the cherry rootstocks such as 'Ferci SL 405' and INRA SL 64, L-2, GM 79 and F $12 / 1$ were the selections of the following diploid species: P. mahaleb, P. lannesiana, P. canescens and $P$. avium, respectively. In turn, other diploid cherry rootstocks are generally the hybrids of diploid parental species mentioned above and some other diploids such as P. incisa, P. pseudocerasus and P. tomentosa. Only diploid $\mathrm{PiKu} 3$ has more complicated pedigree, which comprises two diploid and one tetraploid genotypes. In the case of triploid cherry rootstocks, all of them are the hybrids of diploid and tetraploid species, with one exception of $\mathrm{PiKu} 4$, which has in its pedigree three diploid species. In the latter, one of the parent genotypes is $P$. avium for which, except of diploid, also triploid and tetraploid forms are known (Das et al., 2011). On the other hand, $\mathrm{PiKu} 4$ can be a hybrid of only diploid parents where one of them could be a donor of unreduced gamete $2 \mathrm{n}$. Such phenomenon is widespread within Prunus genus (Wang et al., 2018).

In the case of plum rootstocks evaluated in our study, their ploidy levels correspond well with their origin. All of the diploid rootstock genotypes were selected from diploid species or are the interspecific hybrids of diploid species. Tetraploid 'Fereley Jaspi' has probably tetraploid parental forms of $P$. salicina and $P$. spinose. In pentaploid plum rootstock 'Mariana $\mathrm{P}$ 8.13', probably one of the parents is tetraploid or hexaploid form of $P$. cerasifera since such forms are often found (Das et al., 2011). It has been documented that autopolyploids of $P$. pseudocerasus can produce during meiosis multiple fertile gametes with complete chromosome sets, e.g., $4 n$, leading to formation of pentaploids (Ramsey, Schemske, 1998). We suppose that similar phenomenon could occur also in autopolyploid $P$. cerasifera, which, apart from diploid $P$. munsoniana, was the second parent of the plum rootstock $P$ 8.13. In turn, all accessions identified as hexaploids (four plum rootstocks) were selections of hexaploid $P$. domestica or $P$. domestica var. insititia.

For genotypes within a species and genus, the higher ploidy level is generally associated with increased sizes of stomata and leaves as, e.g., in tea (Wachira, 1994), banana and plantain (Vandenhout et al., 1995) or mulberry (Laltanmawii, Roychowdhuri, 2010). Although, in Prunus rootstocks, comparison of averages for ploidy levels showed a certain tendency to increase the stomata and leaf size along with an increase in the ploidy level; however, the correlations between these traits were not so evident within the genus Prunus (plum and cherry rootstocks) as compared to the high positive correlation between nuclear DNA amount and stomatal length found for the cultivars of the species Malus $\times$ domestica (Tatum et al., 2005; Korban et al., 2009; Podwyszyńska et al., 2016). This probably results from the fact that the genus Prunus includes many various species and hybrids, for which phenotypic and genetic variability is much higher compared to variability of the cultivars within one species such, e.g., Malus $\times$ domectica. Thus, in plum rootstocks, the smallest $(19.6 \mu \mathrm{m})$ stomata were found in pentaploid (P 8.13) and in contrast, the largest $(30.2 \mu \mathrm{m})$ stomata were recorded in one of the diploid genotype (GF 677). So stomata and leaf size cannot be considered as a morphological marker indicating ploidy level for Prunus rootstocks. Moreover, there is no correlation between ploidy level and vigour of individual rootstocks.

The evaluated nuclear DNA contents / ploidy levels as well as stomata and leaf size are the additional descriptors of Prunus rootstock genotypes that can be useful for identifying genotypes. In addition, it is well known that polyploids with an odd number of chromosome sets, e.g., triploids or pentaploids, are low-fertile or infertile (Bharadwaj, 2015). Therefore, the knowledge about the ploidy level of a given Prunus genotype can be useful for planning breeding programs. It can be helpful in the selection of parental forms for crosses and allows predicting the reproductive abilities of hybrids.

\section{Conclusions}

1. Genome sizes of 31 Prunus of rootstocks for plum and cherry trees were evaluated using flow cytometry (FCM) analysis. In plum rootstocks, five diploid, one tetraploid, one pentaploid and four hexaploid genotypes were detected while in rootstocks for cherry trees, nine diploid, nine triploid and two tetraploid genotypes were identified.

2. The tendency to increase the size of stomata and leaves along with an increase in the ploidy level is observed within Prunus rootstocks for cherry trees. In plum rootstocks, only hexaploids have on average significantly larger stomata and leaves compared to other ploidy levels. However, the correlations between these traits are not so evident. Therefore, stomata and leaf size cannot be considered as a morphological marker indicating ploidy level. 
3. There is no correlation between ploidy level and vigour of individual rootstocks.

4. The evaluated nuclear DNA contents / ploidy levels as well as stomata and leaf size are the additional, useful descriptors for identifying Prunus rootstock genotypes.

\section{Acknowledgements}

This work was performed in the frame of multiannual programme on preservation of gene bank resources financed by the Polish Ministry of Agriculture and Rural Development: task 1.3 "Collecting, preservation in ex situ collections, cryoconservation, evaluation, documentation and using of gene bank resources of horticultural crops".

Received 02062018

Accepted 14062019

\section{References}

1. Angiosperm Phylogeny Group. 2009. An update of the Angiosperm Phylogeny Group classification for the orders and families of flowering plants: APG III. Botanical Journal of the Linnean Society, 161 (2): 105-121.

https://doi.org/10.1111/j.1095-8339.2009.00996.x

2. Arumuganathan K., Earle E. D. 1991. Nuclear DNA content of some important plant species. Plant Molecular Biology Reporter, 9: 208-218.

https://doi.org/10.1007/BF02672069

3. Baird W. V., Estager A. S., Wells J. K. 1994. Estimating nuclear DNA content in peach and related diploid species using laser flow cytometry and DNA hybridization. Journal of the American Society for Horticultural Science, 119 (6): 1312-1316.

https://doi.org/10.21273/JASHS.119.6.1312

4. Ben Tamarzizt H., Walker D., Ben Mustapha S., Abdallah D., Baraket G., Salhi Hannachi A., Zehdi Azzouzi S. 2015. DNA variation and polymorphism in Tunisian plum species (Prunus spp.): contribution of flow cytometry and molecular markers. Genetics and Molecular Research, 14 (4): 18034-18046.

https://doi.org/10.4238/2015.December.22.30

5. Bharadwaj D. N. 2015. Polyploidy in crop improvement and evolution. Bahadur B. et al. (eds). Plant Biology and Biotechnology. Springer, p. 619-638. https://doi.org/10.1007/978-81-322-2286-6 24

6. Das B., Ahmed N., Singh P. 2011. Prunus diversity-early and present development: a review. International Journal of Biodiversity and Conservation, 3 (14): 721-734. https://doi.org/10.5897/IJBCX11.003

7. Dickson E. E., Arumuganathan K., Kresovich S., Doyle J. J. 1992. Nuclear DNA content variation within the Rosaceae. American Journal of Botany, 79: 1081-1086. https://doi.org/10.1002/j.1537-2197.1992.tb13697.x

8. Dirlewanger E., Denoyes-Rothan B., Yamamoto T., Chagné D. 2009. Genomics tools across Rosaceae species. Folta K. M., Gardiner S. E. (eds). Genetics and genomics of Rosaceae. Springer, p. 539-561.

https://doi.org/10.1007/978-0-387-77491-6_26

9. Doležel J., Sgorbati S., Lucretti S. 1992. Comparison of three DNA fluorochromes for flow cytometric estimation of nuclear DNA content in plants. Physiologia Plantarum, 85 (4): 625-631. https://doi.org/10.1111/j.1399-3054.1992.tb04764.x

10. Doležel J., Doleželová M., Novák F. J. 1994. Flow cytometric estimation on nuclear DNA amount in diploid bananas (Musa acuminata and M. balbisiana). Biologia Plantarum, 36: 351-357.

https://doi.org/10.1007/BF02920930
11. Dyki B., Habdas H. 1996. The method of isolation of epidermis of tomato and cucumber leaves for microscopic investigation of pathogenic fungus development. Acta Agrobotanica, 49: 123-129 (in Polish). https://doi.org/10.5586/aa.1996.013

12. Galbraith D.W., Harkins K. R., Maddox J. M., Ayres N. M., Sharma D. P., Firoozabady E. 1983. Rapid flow cytometric analysis of the cell cycle in intact plant tissues. Science, 220: 1049-1051.

https://doi.org/10.1126/science.220.4601.1049

13. Gu C., Liu Q. Z., Khan M. A., Wu J., Zhang S. L. 2014. Hetero-diploid pollen grains that represent selfcompatibility are incompatible with non-self receptors in tetraploid Chinese cherry (Prunus pseudocerasus Lindl). Tree Genetics and Genomes, 10 (3): 1-7. https://doi.org/10.1007/s11295-014-0708-2

14. Jedrzejczyk I., Sliwinska E. 2010. Leaves and seeds as materials for flow cytometry estimation of the genome size of 11 Rosaceae woody species containing DNA-staining inhibitors. Journal of Botany, 2010: 1-9. https://doi.org/10.1155/2010/930895

15. Korban S. S., Wannarat W., Rayburn C. M., Tatum T. C., Raybur A. L. 2009. Genome size and nucleotypic variation in Malus germplasm. Genome, 52: 149-155. https://doi.org/10.1139/G08-109

16. Laltanmawii, Roychowdhuri S. 2010. Effects of chromosomal variations on morphology and leaf anatomical behaviours in mulberry (Morus sp.). Journal of Crop and Weed, 6 (2): 35-39.

17. Lysák M. A., Doležel J. 1998. Estimation of nuclear DNA content in Sesleria (Poaceae). Caryologia, 51: 123-132. https://doi.org/10.1080/00087114.1998.10589127

18. Murri G., Massetani F., Giusti S., Finari A., Neri D. 2013. Yield and fruit quality of 'Fortune' plum grafted on 17 rootstocks in replant soil conditions of Central Italy. Acta Horticulturae, 985: 121-126. https://doi.org/10.17660/ActaHortic.2013.985.15

19. Okie W. R., Weinberger J. H. 1996. Plums. Janick J., More J. N. (eds). Fruit breeding. Vol. 1. Tree and tropical fruits, p. 559-607.

20. Podwyszyńska M., Kruczyńska D., Machlańska A., Dyki B., Sowik I. 2016. Nuclear DNA content and ploidy level of apple cultivars including Polish ones in relation to some morphological traits. Acta Biologica Cracoviensia, series Botanica, 58 (1): 81-93. https://doi.org/10.1515/abcsb-2016-0008

21. Pooler M., Ma H., Kidwell-Slak D. 2012. Interploid hybridizations in ornamental cherries using Prunus maackii. Journal of Environmental Horticulture, 30: 89-92.

22. Prunus Vulnerability Statement. 2017. Prunus Crop Germplasm Committee, p. 1-13. www.ars-grin.gov/npgs/ cgc_reports/prunusvuln2017.pdf

23. Ramsey J., Schemske D. W. 1998. Pathways, mechanisms, and rates of polyploid formation in flowering plants. Annual Review of Ecology and Systematics, 29: 467-501. https://doi.org/10.1146/annurev.ecolsys.29.1.467

24. Sitarek M. 2017. Status of sweet cherry rootstocks collection at the RIH in Skierniewice, Poland, and performance of five clonal rootstocks in the orchard. Acta Horticulturae, 1161: 327-329.

https://doi.org/10.17660/ActaHortic.2017.1161.53

25. Śliwińska E. 2008. Estimation of DNA content in plants using flow cytometry. Postępy Biologii Komórki, 35 (suppl. 24): 165-176 (in Polish).

26. Tatum T. C., Stepanovic S., Biradar D. P., Rayburn A. L., Korban S. S. 2005. Variation in nuclear DNA content in Malus species and cultivated apples. Genome, 48 (5): 924-930. https://doi.org/10.1139/g05-033

27. Usenik V., Donik Purgaj B., Fajt N. 2017. Evaluation of five rootstocks with cherry cultivars 'Kordia' and 'Regina' at two locations in Slovenia. Acta Horticulturae, 1161: 261-266. https://doi.org/10.17660/ActaHortic.2017.1161.42 
28. Van Tuyl J. M., Boon E. 1997. Variation in DNA content in the genus Lilium. Acta Horticulturae, 430: 829-836. https://doi.org/10.17660/ActaHortic.1997.430.132

29. Vandenhout H., Ortiz R., Vuylsteke D., Swennen R., Bai K. V. 1995. Effect of ploidy on stomatal and other quantitative traits in plantain and banana hybrids. Euphytica, 83 (2): 117-122. https://doi.org/10.1007/BF01678038

30. Vujović T., Cerović R., Ružić D. 2012. Ploidy level stability of adventitious shoots of sour cherry Čačanski Rubin and Gisela 5 cherry rootstock. Plant Cell, Tissue and Organ Culture, 111: 323-333.

https://doi.org/10.1007/s11240-012-0197-7

31. Wachira F. N. 1994. Triploidy in tea (Camellia sinensis): effect on yield and yield attributes. Journal of Horticultural Science, 69 (1): 53-60. https://doi.org/10.1080/14620316.1994.11515248

32. Wang Y., Du H. M., Zhang J., Chen T., Chen Q., Tang H. R., Wang X. R. 2018. Ploidy level of Chinese cherry (Cerasus pseudocerasus Lindl.) and comparative study on karyotypes with four Cerasus species. Scientia Horticulturae, 232: 46-51.

https://doi.org/10.1016/j.scienta.2017.12.065
33. Zonneveld B. J. M. 2009. The systematic value of nuclear genome size for "all" species of Tulipa L. (Liliaceae). Plant Systematics and Evolution, 281: 217-245.

https://doi.org/10.1007/s00606-009-0203-7

34. Zonneveld B. J. M. 2010. The involvement of Narcissus hispanicus Gouan in the origin of Narcissus bujei and of cultivated trumpet daffodils (Amaryllidaceae). Anales del Jardín Botánico de Madrid, 67 (1): 29-39. https://doi.org/10.3989/ajbm.2219

35. Žabka M., Durišová L'., Eliáš P., Baranec T. 2018. Genome size and ploidy level among wild and cultivated Prunus taxa in Slovakia. Biologia, 73 (2): 121-128. https://doi.org/10.2478/s11756-018-0014-9

ISSN 1392-3196 / e-ISSN 2335-8947

Zemdirbyste-Agriculture, vol. 107, No. 1 (2020), p. 71-78

DOI $10.13080 /$ z-a.2020.107.010

\title{
Prunus genties poskiepių iš Lenkijos genetinių išteklių branduolio DNR kiekis ir fenotipiniai požymiai
}

\author{
M. Podwyszyńska, M. Sitarek, A. Marasek-Ciołakowska, U. Kowalska
}

Skernevicių sodininkystès ir daržininkystes tyrimų institutas, Lenkija

\begin{abstract}
Santrauka
Ploidiškumo lygis gali būti naudingas vertinant reprodukcinị ir somatinị suderinamumą, kuris yra svarbus parametras jskiepių ir poskiepių selekcinèse programose. Branduolio DNR kiekio ịvertinimas buvo atliktas siekiant nustatyti 31 Prunus genties (slyvos, vyšnios ir trešnès) vaismedžių ploidiškumą. Pirmajame tyrimo etape buvo optimizuotos srovinès citometrijos analizės sąlygos naudojant propidžio jodidą (PJ) DNR dažymui. Pakartojami rezultatai ir palyginti geros kokybès histogramos buvo gauta naudojant ekstrahavimo buferi, papildytą $1 \%$ polivinilpirolidono (PVP), inkubuojant nuo 50 iki 90 minučių.

Geriausias srovinès citometrijos analizės vidinis standartas poskiepiams, kuriu branduolio DNR kiekis yra nuo 0,55 iki 1,64 pg, buvo valgomasis pomidoras (Solanum lycopersicum L.) $2 \mathrm{C}=1,96 \mathrm{pg}$, o poskiepiams su didesniu branduolinės DNR kiekiu (1,8-2,3 pg) - gauruotoji soja (Glycine max (L.) Merr.) 2,50 pg. Penkiuose slyvos poskiepiuose $2 \mathrm{C}$ vertès svyravo nuo $0,61 \mathrm{iki} 0,67 \mathrm{pg}$; tai rodè jų diploidini chromosomų skaičių. Vienas poskiepis buvo identifikuotas kaip tetraploidas $(2 \mathrm{C}=1,34 \mathrm{pg})$, keturi poskiepiai - kaip heksaploidai, kurių DNR kiekis buvo nuo 2,07 iki 2,23 pg. Vienas poskiepis identifikuotas kaip pentaploidas dèl jo 1, $64 \mathrm{pg} 2 \mathrm{C}$ vertès; tai buvo apie 2,5 karto daugiau nei diploidinèje Prunus sp. Devyniuose vyšnios poskiepiuose 2C DNA vertės svyravo nuo 0,74 iki $0,86 \mathrm{pg}$; tai rodè ju diploidini chromosomu skaičiu. Devyni vyšnios poskiepiai buvo identifikuoti kaip triploidai, kuriu 2C DNR kiekis svyravo nuo 1,03 iki 1,24 pg. Du vyšnios poskiepiai identifikuoti kaip tetraploidai, kurių 2C DNR kiekis buvo 1,39 pg. Vyšnios ir slyvos poskiepiu ploidiškumo lygis buvo ịvertintas atsižvelgiant i morfologinius ir agronominius požymius. Prunus poskiepio genotipuose didèjant ploidiškumo lygiui nustatyta žiotelių ir lapų didèjimo tendencija, tačiau koreliacijos tarp šių požymių nebuvo tokia akivaizdi. Taigi, žiotelių ir lapu dydis negali būti laikomas morfologiniu žymekliu, rodančiu ploidiškumo lygị. Ivertintas branduolinės DNR kiekis / ploidiškumo lygis, taip pat ir žiotelių ir lapų dydis yra papildomi Prunus poskiepių deskriptoriai, kurie gali būti naudingi identifikuojant genotipus.
\end{abstract}

Reikšminiai žodžiai: heksaploidai, pentaploidai, ploidiškumo lygis, slyva, srovinè citometrija, tetraploidai, triploidai, vyšnios poskiepiai. 